\title{
Pharmacokinetics, Biodistribution, and Toxicity Evaluation of Anti-SEMA3A (F11) in In Vivo Models
}

\author{
JAEHYUN LEE ${ }^{1,2^{*}}$, DONGGEON KIM ${ }^{2}$, EUNJU SON ${ }^{2}$, SU-JI YOO ${ }^{2}$, JASON K. SA ${ }^{2}$, \\ YONG JAE SHIN ${ }^{2}$, YEUP YOON ${ }^{1,2}$ and DO-HYUN NAM ${ }^{1,2,3}$ \\ ${ }^{1}$ Department of Health Sciences and Technology, Samsung Advanced Institute for Health Sciences and Technology, \\ Sungkyunkwan University, Seoul, Republic of Korea; \\ ${ }^{2}$ Institute for Refractory Cancer Research, Research institute for Future Medicine, \\ Samsung Medical Center, Seoul, Republic of Korea; \\ ${ }^{3}$ Department of Neurosurgery, Samsung Medical Center, \\ Sungkyunkwan University School of Medicine, Seoul, Republic of Korea
}

\begin{abstract}
Background/Aim: The aim of our study was to investigate the pharmacokinetics (PK), tissue distribution and toxicity of F11 antibody to semaphorin $3 A$ in mouse models and explore its anti-angiogenic and tumor-inhibitory effect. Materials and Methods: Patient-derived xenograft (PDX) models were established via subcutaneous implantation of glioblastoma multiforme (GBM) cells and treated with F11. Results: F11 significantly attenuated tumor growth and angiogenesis in the GBM PDX model. Within the range of administered doses, the $P K$ of $F 11$ in serum demonstrated a linear fashion, consistent with general PK profiles of soluble antigen-targeting antibodies. Additionally, the clearance level was detected at between 4.63 and $7.12 \mathrm{ml} / \mathrm{d} / \mathrm{kg}$, while the biological half-life was measured at 6.9 and 9.4 days. Tissue distribution of F11 in kidney, liver and heart was consistent with previously reported antibody patterns. However, the presence of F11 in the brain was an interesting finding. Conclusion: Collectively, our results
\end{abstract}

\footnotetext{
*These Authors contributed equally to this work.

Correspondence to: Do-Hyun Nam, MD, Ph.D., Department of Neurosurgery, Samsung Medical Center, Sungkyunkwan University School of Medicine, Seoul 06351, Korea; and Department of Health Sciences and Technology, SAIHST, Sungkyunkwan University, Irwon-ro, Gangnam-gu, Seoul 06351, Republic of Korea. Tel: +82 234103497, Fax: +82 234100048, e-mail: nsnam@skku.edu and Yeup Yoon, Ph.D., Department of Health Sciences and Technology, SAIHST, Sungkyunkwan University; Institute for Retractory Cancer Research, Research Institute for Future Medicine, Samsung Medical Center, Seoul, Republic of Korea. Tel: +82 34100460m e-mail: benedict.yoon@samsung.com.
}

Key Words: Semaphorin3A, SEMA3A, fully human antibody, pharmacokinetics, tissue distribution, toxicity. revealed angiogenic and tumor-inhibitory effect of F11 antibody and its potential therapeutic use within a clinical framework based on $P K$, biodistribution and toxicity evaluation in mouse models.

Semaphorins are a family of membrane-bound and soluble proteins that govern important cellular functions including axonal guidance, cell-cell interaction, cell differentiation and morphology (1-3). Semaphorin 3A (SEMA3A) provides a potential plexin interaction site by binding to neuropilin-1 (NRP1), a main binding receptor of SEMA3A (4-6). Recent studies have identified carcinogenic roles of SEMA3A $(7,8)$. Autocrine SEMA3A is often overexpressed in glioblastoma multiforme (GBM), one of the most malignant brain tumors, and promotes tumor cell dispersal via regulation of substrate adhesion (9). In pancreatic and hepatocellular carcinomas, SEMA3A directly promotes tumor malignancy $(10,11)$ and attracts tumor-associated macrophages to avascular regions in order to both sustain and induce tumor progression $(12,13)$. Administration of bevacizumab has been approved by the United States Food and Drug Administration as a single agent for the treatment of recurrent GBM, however, acquired resistance remains a central barrier to long-term efficacy (14, 15). Previous studies have demonstrated that SEMA3A promotes vascular permeabilization through activating vascular endothelial growth factor (VEGF) signaling pathway and could potentially be employed as a therapeutic target against ischemic disease and cancer $(16,17)$. Moreover, SEMA3A accelerates stabilization of VEGF-induced angiogenesis through recruitment of NRP1-expressing monocytes (18). This evidence highlights SEMA3A as an emerging target for tumor growth inhibition via suppression of angiogenesis. Hence, we screened anti-SEMA3A single-chain variable fragment using synthetic antibody phage library and generated fully human immunoglobulin (Ig) G1 monoclonal antibody to SEMA3A, 
F11, with selective binding affinity to both human and mouse SEMA3A. We confirmed that the neutralizing effect of F11 directly confers inhibition of tumor growth and tumorassociated macrophage distribution in GBM patient-derived xenograft (PDX) models in our previous report (19).

SEMA3A is widely expressed in various non-neoplastic cell types, including endothelial cells and epithelium (20, 21). Direct binding activity with normal tissues may largely affect pharmacokinetics (PK) and toxicity of anti-SEMA3A. However, the tissue distribution and toxicity of SEMA3Atargeting agents remain relatively unexplored. Therefore, we investigated F11 to analyze detailed biodistribution and toxicity level in mouse models. The comprehensive understanding of PK, tissue distribution, and toxicity profiles of F11 in mice would be an important step towards clinical trials and commercial development.

In order to gain insight into the $\mathrm{PK}$, tissue distribution and acute toxicity of $\mathrm{F} 11, \mathrm{BALB} / \mathrm{c}$ mouse models were administered F11 in a dose-escalation manner. Overall, we present therapeutic efficacy of F11 as an anticancer agent with neovascular inhibition in GBM PDX model and in vivo profiling of $\mathrm{PK}$, biodistribution and toxicity.

\section{Materials and Methods}

Pharmacokinetics study in BALB/c mice. For the PK study, female BALB/c mice (6 weeksold, 18-20 g) were obtained from Orient Bio Inc. (Seongnam, Korea). Mice were received a single intravenous (i.v.) injection dose of 5 or $25 \mathrm{mg} / \mathrm{kg}$ of F11 (Samsung Medical Center, Seoul, Korea) via tail vein injection ( $n=30 /$ each dose). All mouse experiments were performed according to the Association for Assessment and Accreditation of Laboratory Animal Care-accredited guidelines of the Laboratory Animal Research Center at the Samsung Medical Center. Blood samples were acquired from three mice per group via cardiac puncture. Serum samples were collected at various time points (5 and $30 \mathrm{~min}, 1,4$ and $8 \mathrm{~h}$; and 1, 4, 7, 14 and $22 \mathrm{~d}$ ) after F11 administration for measurement of PK parameters.

Analysis of F11 concentration in mouse serum. Serum samples were analyzed for F11 concentration using sandwich enzyme-linked immunosorbent assay (ELISA). Flat-bottom 96-well plates (Costar, Washington, DC, USA) were coated with $1 \mu \mathrm{g} / \mathrm{ml}$ of AffiniPure Goat Anti-Human IgG, Fc $\gamma$ Fragment Specific (Jackson Immunoresearch, West Grove, PA, USA) at $4^{\circ} \mathrm{C}$ overnight. Next day, the coated 96 -well plates were blocked by $3 \%$ skim milk at room-temperature for $1 \mathrm{~h}$ and the harvested mouse serum was added into the 96-well plates. After washing using phosphate-buffered saline with Tween-20 $(0.1 \%)$, bound F11 in serum was detected using Goat anti-Human IgG F(ab')2 Secondary Antibody (Thermo Fisher Scientific, Waltham, MA, USA). Triplicate serum samples were analyzed through ELISA.

Tumor model. GBM specimens were obtained from patients undergoing surgery at Samsung Medical Center (SMC) in accordance with its Institutional Review Board. Patient-derived cells (PDCs) were injected into the subcutaneous region of six-week-old female BALB/c nude mice. The tumor-bearing mice were regrouped when the mass

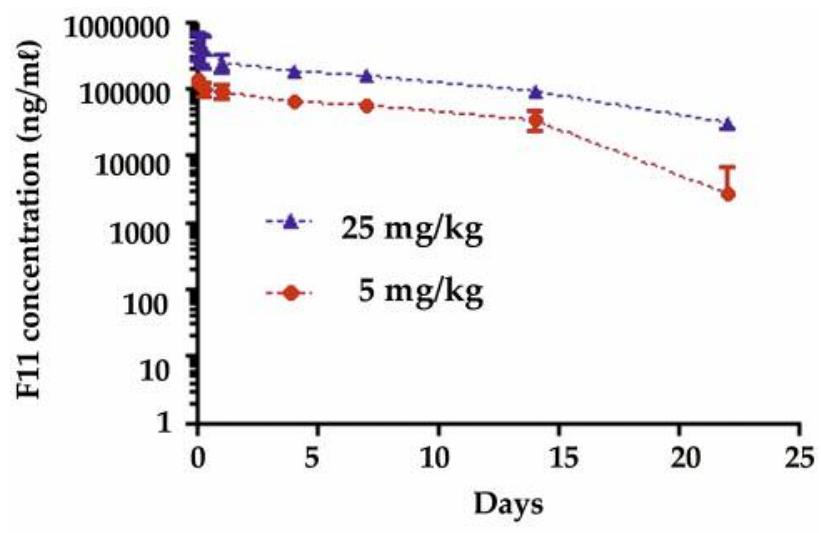

Figure 1. Pharmacokinetics of antibody to semaphorin $3 A$ (SEMA3A) (F11). Serum F11 concentration versus time profile after intravenous administration in BALB/c mice. Data are the mean pharmacokinetic parameters of each group with three animals.

volume reached an average of $150 \mathrm{~mm}^{3}$. F11 and phosphate-buffered saline were administered via intravenous (i.v.) injection at $5 \mathrm{mg} / \mathrm{kg}$, twice a week, for 18 days. Mice with body weight loss greater than $20 \%$ were sacrificed. All mouse experiments were performed according to the Association for Assessment and Accreditation of Laboratory Animal Care-accredited guidelines of the Laboratory Animal Research Center at the Samsung Medical Center.

Immunofluorescence analysis. Subcutaneous tumors from the mice above were fixed in 5\% paraformaldehyde and embedded in paraffin. To evaluate the degree of tumor neoangiogenesis, paraffin sections were stained with anti-CD31 (BD, Franklin Lakes, NJ, USA, 553370). Alexa Fluor 594 goat anti-rat (Life Technology, Carlsbad, CA, USA, A11007) was used for anti-CD31 detection in mouse tumor tissue.

Immunohistochemistry. In order to determine the F11 distribution in vivo, brain, liver, kidney, spleen, and heart were isolated from mice treated with F11 $(5,25,200 \mathrm{mg} / \mathrm{kg}$, i.v. $)$. The resulting tissue samples were fixed using $4 \%$ formaldehyde solution for $24 \mathrm{~h}$ prior to paraffin embedding. The paraffin block was sectioned at $4 \mu \mathrm{m}$ thickness and tissue distribution of F11 was detected by immunohistochemical staining. Goat anti-Human IgG F(ab')2 Secondary Antibody (Thermo Fisher Scientific) was used for F11 detection in mouse tissues and the SEMA3A expression was analyzed using anti-SEMA3A (Abcam, Cambridge, UK).

Serum chemistry. Mouse blood samples were collected in vacuum tubes devoid of anticoagulants, allowing blood to clot in room temperature for $1 \mathrm{~h}$. After blood clot observation, the tubes were centrifuged at $845 \times g$ for $15 \mathrm{~min}$ and the serum layer was separated. To evaluate acute toxicity after F11 treatment, serum levels of glutamic pyruvic transaminase (GPT), glutamic oxaloacetic transaminase (GOT), alanine aminotransferase (ALT), blood urea nitrogen (BUN), and creatine were measured by Fuji DRI-Chem 7000i (Fuji, Tokyo, Japan).

Statistical analysis. Statistical significance of differences was evaluated by Student $t$-test. 


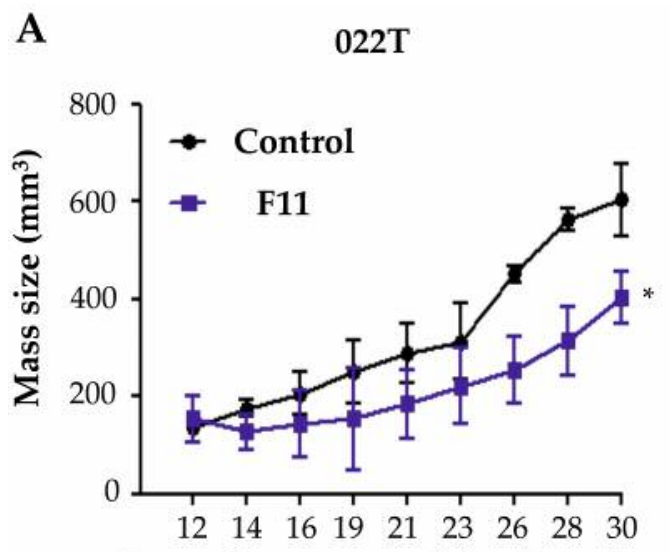

Days after tumor cell implantation
B
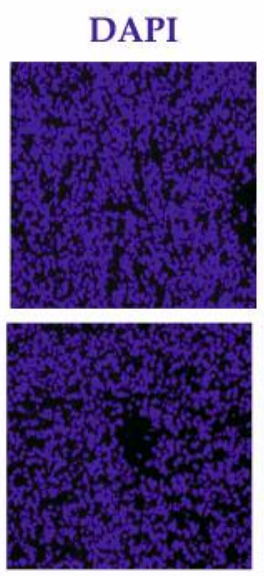

CD31
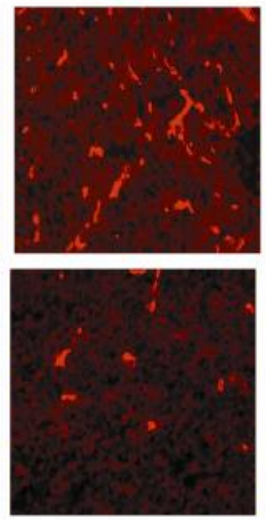

MERGE
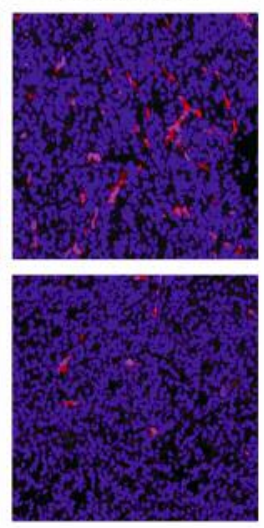

C
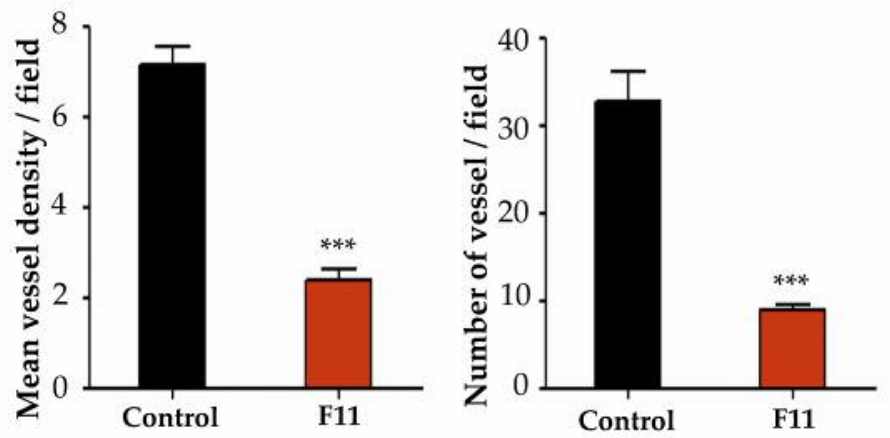

Figure 2. F11 inhibits tumor growth through reducing vascularization in the tumor region. A: Mice bearing glioblastoma patient-derived cell (022T) received intravenous injection with $5 \mathrm{mg} / \mathrm{kg} F 11$ twice per week. B: Confocal analysis of CD31 immunofluorescence staining in subcutaneous tumor tissue of control and F11-treated mice. C: Mean vessel density and number of vessel in each group were measured; data are representative of at least five independent fields. Significantly different at $* p<0.05$ and $* * * p<0.005$. DAPI: 4',6-Diamidino-2-phenylindole.

Table I. F11 pharmacokinetic parameters after intravenous administration in BALB/c mice calculated by compartmental pharmacokinetic analysis. Data for mice are from a pooled analysis of 30 mice per dose level.

\begin{tabular}{|c|c|c|c|c|c|c|c|c|c|}
\hline Strain & $\begin{array}{c}\text { F11 } \\
\text { dose } \\
(\mathrm{mg} / \mathrm{kg})\end{array}$ & $\begin{array}{l}\text { Area under } \\
\text { the moment } \\
\text { curve } 0 \text {-inf } \\
(\mu \mathrm{g} / \mathrm{ml} \text { day })\end{array}$ & $\begin{array}{c}\mathrm{T}_{1 / 2} \\
\text { (initial) } \\
\text { (days) }\end{array}$ & $\begin{array}{c}\mathrm{T}_{1 / 2} \\
\text { (terminal) } \\
\text { (days) }\end{array}$ & $\begin{array}{l}\text { Clearance } \\
(\mathrm{ml} / \mathrm{d} / \mathrm{kg})\end{array}$ & $\begin{array}{c}\text { Volume at } \\
\text { steady- } \\
\text { state } \\
(\mathrm{ml} / \mathrm{kg})\end{array}$ & $\begin{array}{l}\text { Mean } \\
\text { residence } \\
\text { time } \\
\text { (days) }\end{array}$ & $\begin{array}{c}\text { Maximum } \\
\text { serum } \\
\text { concentration } \\
(\mu \mathrm{g} / \mathrm{ml})\end{array}$ & $\begin{array}{l}\text { Time taken to } \\
\text { reach maximum } \\
\text { concentration } \\
\text { (days) }\end{array}$ \\
\hline \multirow[t]{2}{*}{$\mathrm{BALB} / \mathrm{c}$} & 5 & 1079.896 & 0.023 & 6.934 & 4.63 & 46.262 & 9.99 & 145.680 & 0.003 \\
\hline & 25 & 3512.602 & 0.434 & 9.394 & 7.12 & 92.598 & 13.01 & 485.084 & 0.003 \\
\hline
\end{tabular}

\section{Results}

Analysis of F11 PK in BALB/c mice. We generated a F11 monoclonal antibody to SEMA3A as a potential therapeutic antibody against GBM progression (19). The PK profiles of F11 were assessed through administration of a single i.v. bolus dose in BALB/c mice at 5 or $25 \mathrm{mg} / \mathrm{kg}$ (Figure 1). The value of the area under the moment curve extrapolated to infinity was increased 3.5-fold and the clearance rate also increased in parallel with the administered dose, ranging from $4.63 \mathrm{ml} / \mathrm{d} / \mathrm{kg}$ at $5 \mathrm{mg} / \mathrm{kg}$ to $7.12 \mathrm{ml} / \mathrm{d} / \mathrm{kg}$ at $25 \mathrm{mg} / \mathrm{kg}$. The biological half-life was measured as 6.93 days at 5 
A Female BALB/c

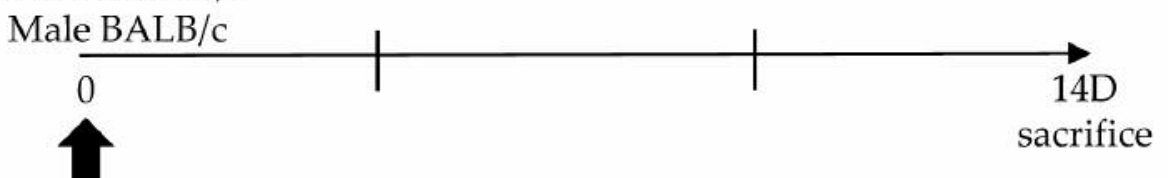

Intravenous injection

$(5,25,50,100,200 \mathrm{mg} / \mathrm{ml})$

B

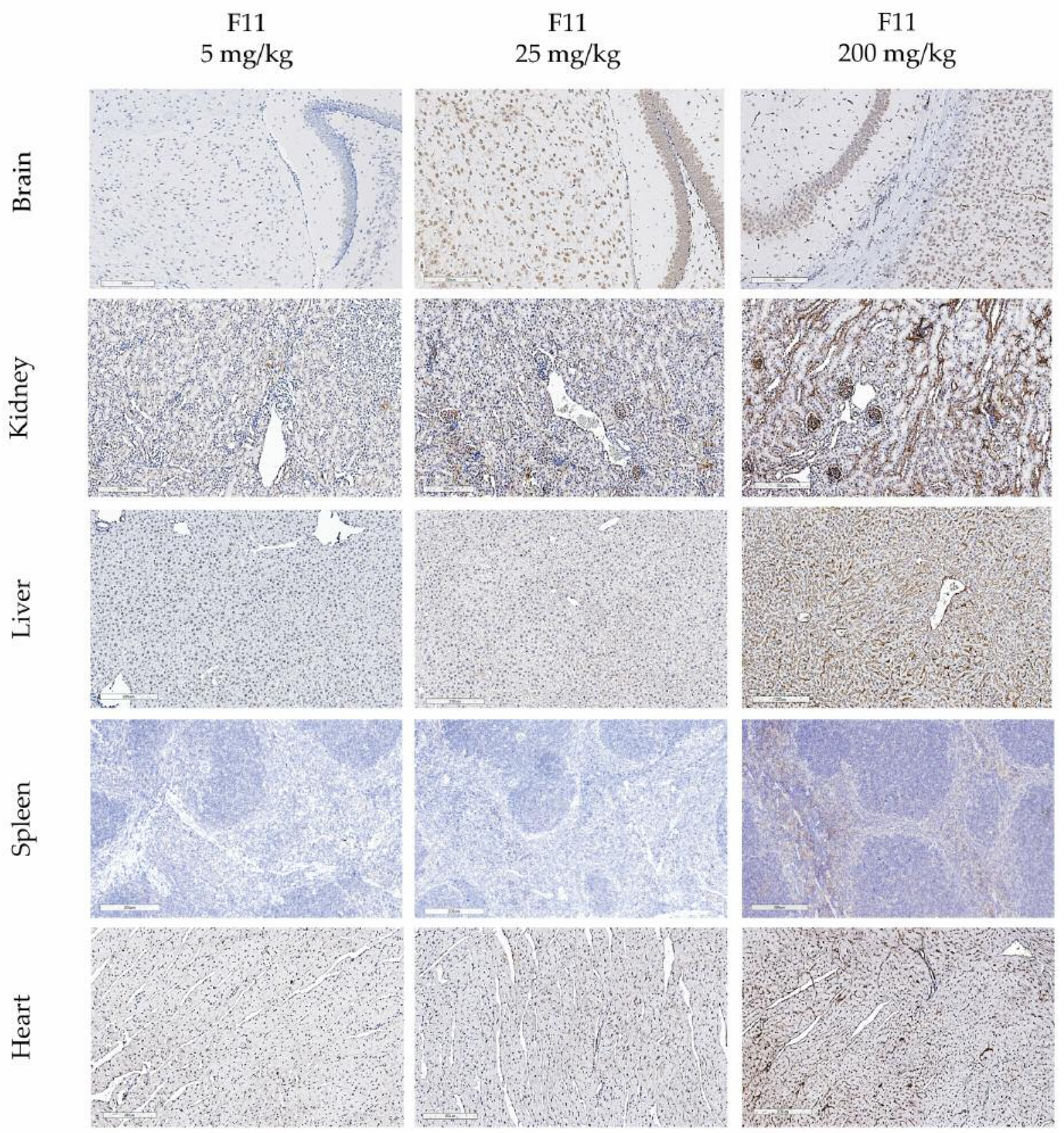

Figure 3. Biodistribution of F11. A: Schematic representation of the time points of F11 injection and time of sacrifice. B: The distribution F11 at 5, 25, $200 \mathrm{mg} / \mathrm{kg}$ intravenous administration was evaluated by immunohistochemical analysis using brain, kidney, liver, spleen, and heart. Bar=200 $\mu \mathrm{m}$. 
A

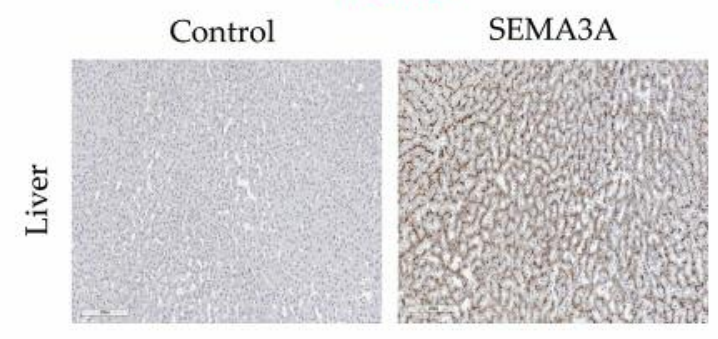

B

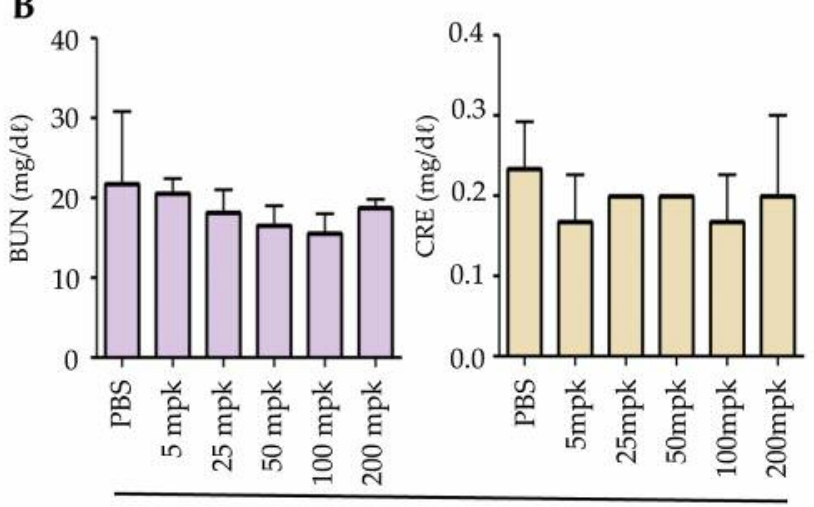

Female
MOUSE
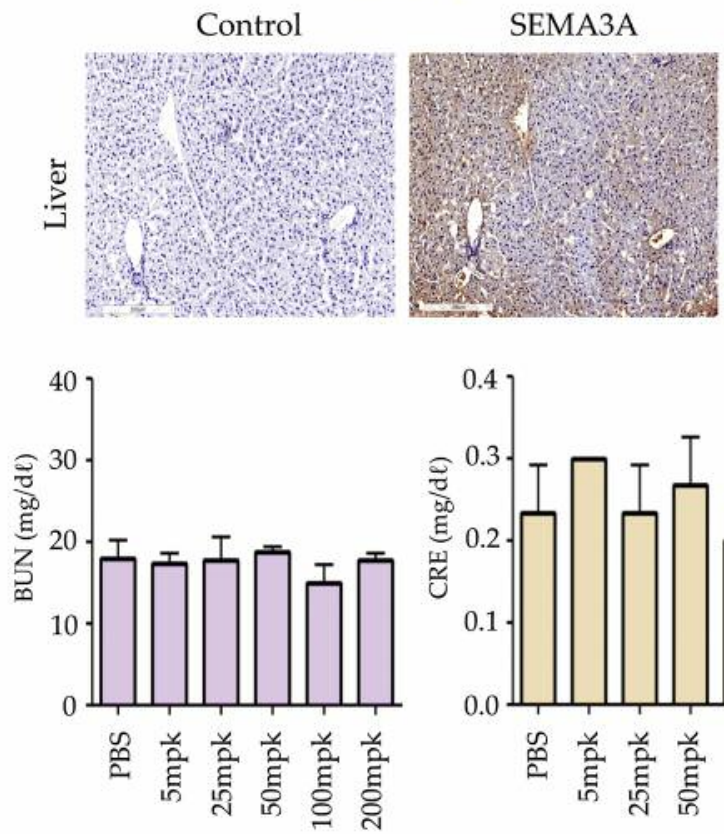

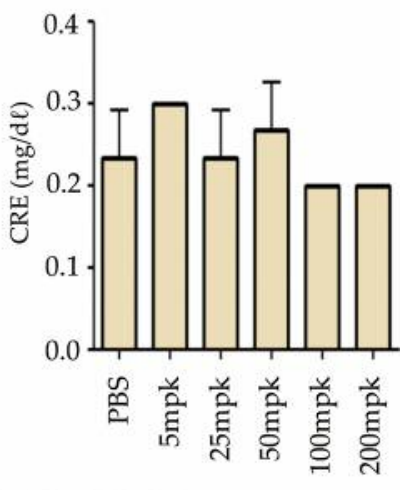

Male

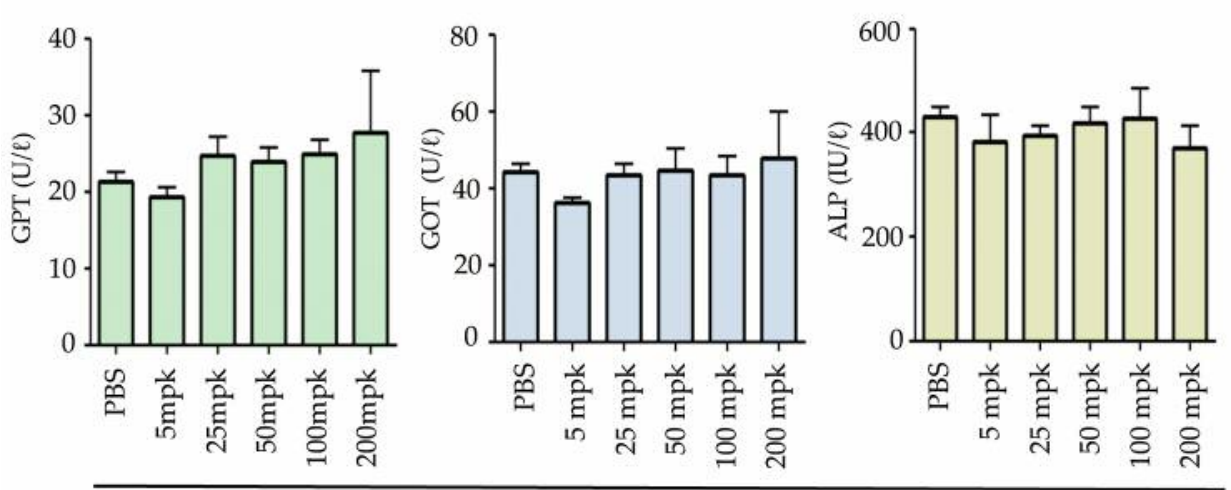

Female
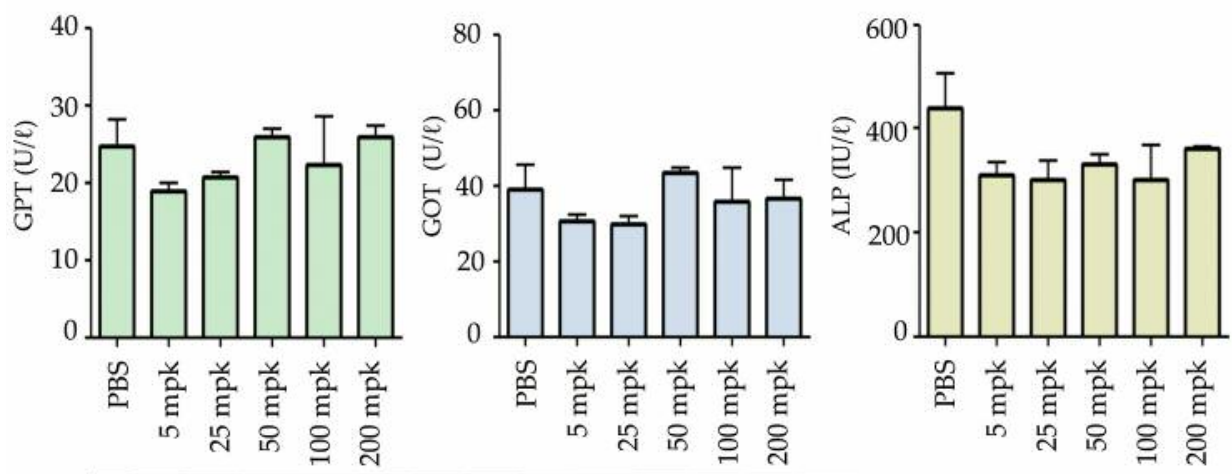

Male

Figure 4. Hepatotoxicity and renal toxicity of F11 in BALB/c mice. A: Semaphorin 3A (SEMA3A) protein expression profile of mouse and human liver tissue. B: Comparison of blood urea nitrogen (BUN), creatine (CRE), glutamate pyruvic transammase (GPT), glutamic oxaloacetic transaminase $(G O T)$ and alanine aminotransferase (ALT) results in accordance with the administered F11. The toxicity groups were composed of female and male BALB/c mice ( $n=3$ mice per dose). 
Table II. The parameters for kidney and liver function assessment in BALB/c mice injected with F11.

\begin{tabular}{|c|c|c|c|c|c|c|c|c|c|c|}
\hline \multirow[b]{2}{*}{ Treatment } & \multicolumn{5}{|c|}{ Females } & \multicolumn{5}{|c|}{ Males } \\
\hline & $\begin{array}{l}\text { Blood } \\
\text { urea } \\
\text { nitrogen } \\
(\mathrm{mg} / \mathrm{dl})\end{array}$ & $\begin{array}{c}\text { Creatine } \\
(\mathrm{mg} / \mathrm{dl})\end{array}$ & $\begin{array}{c}\text { Glutamate } \\
\text { pyruvic } \\
\text { transammase } \\
(\mathrm{U} / \mathrm{l})\end{array}$ & $\begin{array}{c}\text { Glutamic } \\
\text { oxaloacetic } \\
\text { transaminase } \\
(\mathrm{U} / \mathrm{l})\end{array}$ & $\begin{array}{l}\text { Alanine- } \\
\text { amino- } \\
\text { transferase } \\
\text { (IU/l) }\end{array}$ & $\begin{array}{l}\text { Blood urea } \\
\text { nitrogen } \\
(\mathrm{mg} / \mathrm{dl})\end{array}$ & $\begin{array}{l}\text { Creatine } \\
(\mathrm{mg} / \mathrm{dl})\end{array}$ & $\begin{array}{c}\text { Glutamate } \\
\text { pyruvic } \\
\text { transaminase } \\
(\mathrm{U} / \mathrm{l})\end{array}$ & $\begin{array}{c}\text { Glutamic } \\
\text { oxaloacetic } \\
\text { transaminase } \\
(\mathrm{U} / \mathrm{l})\end{array}$ & $\begin{array}{c}\text { Alanine- } \\
\text { amino- } \\
\text { transferase } \\
\text { (IU/l) }\end{array}$ \\
\hline PBS & $21.8 \pm 8.9$ & $0.23 \pm 0.05$ & $21.3 \pm 1.2$ & $44.3 \pm 2.1$ & $432 \pm 17.1$ & $17.9 \pm 2.3$ & $0.23 \pm 0.05$ & $24.7 \pm 3.5$ & $39 \pm 6.6$ & $441 \pm 64.1$ \\
\hline $5 \mathrm{mg} / \mathrm{kg} \mathrm{F} 11$ & $20.4 \pm 1.9$ & $0.17 \pm 0.05$ & $19.3 \pm 1.2$ & $36.3 \pm 1.2 *$ & $382 \pm 52.9$ & $17.4 \pm 1.1$ & $0.30 \pm 0.00$ & $19 \pm 1.0$ & $30.7 \pm 1.5$ & $309 \pm 25.7$ \\
\hline $25 \mathrm{mg} / \mathrm{kg} \mathrm{F} 11$ & $18.1 \pm 2.9$ & $0.2 \pm 0.00$ & $24.7 \pm 2.5$ & $43.3 \pm 3.1$ & $395 \pm 17.1^{* *}$ & $17.7 \pm 2.9$ & $0.23 \pm 0.05$ & $20.7 \pm 0.6$ & $30 \pm 2.0$ & $301 \pm 35.6$ \\
\hline $50 \mathrm{mg} / \mathrm{kg} \mathrm{F} 11$ & $16.6 \pm 2.5$ & $0.2 \pm 0.00$ & $24 \pm 1.7$ & $44.7 \pm 5.7$ & $418.7 \pm 31.3$ & $18.7 \pm 0.7$ & $0.27 \pm 0.06$ & $26 \pm 1.0$ & $43.3 \pm 1.5$ & $331 \pm 16.9$ \\
\hline $100 \mathrm{mg} / \mathrm{kg} \mathrm{F} 11$ & $15.5 \pm 2.5$ & $0.17 \pm 0.05$ & $25 \pm 1.7$ & $43.3 \pm 5.1$ & $429 \pm 56.7$ & $14.9 \pm 2.2 * * *$ & $0.2 \pm 0.00$ & $22.3 \pm 6.1$ & $36 \pm 8.5$ & $302 \pm 66.9$ \\
\hline $200 \mathrm{mg} / \mathrm{kg} \mathrm{F} 11$ & $18.8 \pm 1.1$ & $0.2 \pm 0.00$ & $27.7 \pm 8.0$ & $47.7 \pm 12.0$ & $370 \pm 41.5$ & $17.8 \pm 0.7$ & $0.2 \pm 0.00$ & $26 \pm 1.4$ & $36.5 \pm 4.9$ & $361 \pm 4.24$ \\
\hline
\end{tabular}

Data are presented as the mean \pm SD. Significantly different from PBS-treated at $* p<0.05, * * p<0.01$ and $* * * p<0.005$.

$\mathrm{mg} / \mathrm{kg}$ and 9.39 days at $25 \mathrm{mg} / \mathrm{kg}$. Furthermore, the distribution volume at steady-state was from $46-92 \mathrm{ml} / \mathrm{kg}$ at the given doses. The observed maximum serum concentrations $\left(\mathrm{C}_{\max }\right)$ were 145.680 and $485.084 \mu \mathrm{g} / \mathrm{ml}$ at 5 and $25 \mathrm{mg} / \mathrm{kg}$ and the corresponding mean residence times in the body were 9.99 and 13.01 days. The time point at which $\mathrm{C}_{\max }$ was observed was 0.003 day at both doses. Collectively, pharmacokinetics of F11 demonstrated a twocompartment linear trend, consistent with general PK profiles of monoclonal antibodies that target soluble antigens (22). We used the compartmental method for PK analysis using the parameters described in Table I.

SEMA3A antibody (F11) inhibits tumor growth and angiogenesis in PDX GBM model. To explore whether F11 inhibited both tumor growth and angiogenesis in vivo, PDX models of GBM were injected with F11 of $5 \mathrm{mg} / \mathrm{kg}$ twice a week. After 30 days, treatment of F11 demonstrated $30 \%$ decrease in tumor size compared to the control group (Figure 2A). Immunofluorescent analysis of CD31 protein showed a clear reduction in CD31 expression level in F11 treated group compared to the control group (Figure 2B). To investigate the anti-angiogenesis effect of F11, measurement of vessel density and numbers were investigated and exhibited a significant reduction when treated with F11. The mean vessel density and the number of vessels were significantly reduced by $67 \%$ and $72 \%$, respectively, compared to the control group (Figure $2 \mathrm{C}$ ). These results provide compelling evidence that F11 inhibits vascularization and impedes tumor growth in vivo.

The distribution of F11 in dose-escalation study. In order to investigate distribution and acute toxicity of anti-SEMA3A agent, female and male $\mathrm{BALB} / \mathrm{c}$ mice were administered with $5 \mathrm{mg} / \mathrm{kg}$ to $200 \mathrm{mg} / \mathrm{kg}$ of F11. After 2 weeks of treatment, F11-treated mice were sacrificed (Figure 3A).
Notably, there was no treatment-related mortality in the F11treated group. To estimate distribution rate of F11 in mice, we conducted immunohistochemical analysis of brain, kidney, liver, spleen and heart tissue specimens that were acquired from the corresponding mice administered with either 5,25 , or $200 \mathrm{mg} / \mathrm{kg}$ of F11. The majority of tissue specimens from F11-treated mice exhibited positive staining in a dose-dependent manner. At both $25 \mathrm{mg} / \mathrm{kg}$ and $200 \mathrm{mg} / \mathrm{kg}$, strong binding patterns of F11 were observed in brain, kidney, liver, lung (data not shown), and heart tissues, while there were no detectable signals from the $5 \mathrm{mg} / \mathrm{kg}$ treatment level. As a recombinant protein, F11 in kidney, liver and lung showed a similar pattern compared to previously reported antibodies (23), whereas positive staining in brain is a novel finding. The positive signal in brain suggests that F11 has the potential to penetrate through the blood-brain barrier (BBB), and it is necessary to clarify the underlying mechanism of this in future study. Among the target organs, we further investigated the potential impacts of administration of F11. Additionally, we examined both kidney and liver for pre-toxicological assessment during the treatment course.

Hepatotoxicity and renal toxicity of $F 11$ in $B A L B / c$ mice. The immunostaining analysis showed that the SEMA3A was broadly expressed in kidney and liver of both mice and humans (Figure 4A) (24).Based on these results, we further evaluated whether the distribution of F11 in kidney and liver may affect their specific functions. We investigated serum chemistry using serum samples from female and male $\mathrm{BALB} / \mathrm{c}$ mice that were administered 5 to $200 \mathrm{mg} / \mathrm{kg}$ of F11. The BUN and creatine results were used as assessment of kidney function, while GPT, GOT, and ALT were measured for liver function. Notably, serum chemistry results confirmed no acute toxicity of F11 on kidney and liver. In female BALB/c mice, the GTP level slightly increased in a 
dose-dependent manner but the maximum increase was observed to be within the normal GTP range of $\mathrm{BALB} / \mathrm{c}$ mice (Figure 4B). The serum levels of BUN, creatine, GPT, GOT, and ALT from all the F11- treated groups were within the normal range (Table II). Thus, it can be suggested that the presence of F11 in liver and kidney did not induce hepatotoxicity or renal toxicity.

\section{Discussion}

Previous studies have shown SEMA3A to be a chemoattractant in cortical apical dendrites and major components of diffuse chemorepulsive signals $(25,26)$. In recent studies, SEMA3A was often involved in tumor propagation $(10,11)$ and promoted tumor metastasis (9). SEMA3A acts as a chemoattractant factor for tumor-associated macrophages in hypoxic niches, subsequently promoting vascularization $(10,12)$. Therefore, it is evident that SEMA3A is an important therapeutic target in cancer therapy based on its prevalence in tumor progression. We previously demonstrated the tumor- inhibitory effect of F11 in GBM PDX models (19). As F11 has cross-reactivity to both human and mouse SEMA3A, it will be highly important to comprehend the pathological and physiological process of SEMA3A blockade in preclinical models. The pharmacokinetics of F11 were assessed through i.v. injection in mouse models and tissue distributions of F11 in major organs were then examined. As PK, biodistribution and toxicity studies on SEMA3A drugs have rarely been studied previously, our results present an important step towards developing a SEMA3A-mediated therapeutic approach in multiple tumor models.

Detailed PK of F11 are summarized in Table I. In PK analysis, F11 exhibited a linear pharmacokinetic profile at 5 and $25 \mathrm{mg} / \mathrm{kg}$. Antibodies targeting soluble antigen have undergone extensive research in pre-clinical and clinical studies (27-29). For in vivo-administered antibodies, the PK profiles are determined through assessment of target distribution, serum clearance, intrinsic half-life, and tissue distribution, regardless of its subtype $(27,28,30,31)$. Especially in the case of targeting soluble ligands such as $\mathrm{F} 11$, it is important to determine the serum clearance rate and tissue distribution pattern to evaluate in vivo efficacy as well as potential side effects. In present study, we determined that the PK profile of F11 presented a two-compartment linear model with a rapid elimination phase, characterized by a short distribution phase, and more-prolonged elimination half-life, as a result of the non-specific clearance by the reticuloendothelial system and the interaction with neonatal Fc receptor (22). F11 exhibited two-compartment model pharmacokinetics, consistent with those of several other IgG antibodies targeting soluble antigen (30).

Recent studies have shown that the capacity of tumor cells to produce SEMA3A may account for their loss of sensitivity to anti-VEGF-targeted therapy, which in process leads to development of resistance to the VEGF antibody, bevacizumab (16-18). We demonstrated the tumor-inhibitory effect of F11 in vivo and further reduced vascularization in the tumor region via CD31 immunostaining. These results show that F11 potentially could be employed as an antiangiogenic therapy for the treatment of GBM.

We identified that the tissue distribution of F11 in brain, liver, kidney, spleen and heart was proportional to the concentration administered. The tissue distributions in liver, kidney and heart were strongly stained in the high-dose group, consistent with previously reports of general antibody biodistribution patterns (24). The most interesting results was the ability of F11 to move across blood-brain barrier as this was a unique phenomenon for intravenous-injected models. Positive signals in both liver and kidney were consistent with endogenous SEMA3A expression, according to the reference dataset. Therefore, the distribution noted in these organs may reflect the high expression of SEMA3A and subsequent accumulation of F11.

The toxicity related to strong binding to liver and kidney was analyzed using serum chemistry profiling. In female and male BALB/c mice, the serum levels of BUN, creatine, GPT, GOT, and ALT from all F11-treated groups were within the normal range, suggesting the absence of the toxicity of F11, and its potential in a clinical framework.

Collectively, our findings highlight the importance in the assessment of biodistribution and toxicity of F11 in each major organ for its potential implementation in a clinical framework.

\section{Conflicts of Interest}

The Authors declare no conflict of interest in regard to this study.

\section{Acknowledgements}

This research was supported by a grant of the Korea Health Technology R\&D Project through the Korea Health Industry Development Institute (KHIDI), funded by the Ministry of Health \& Welfare, Republic of Korea. (HI14C3418). The biospecimens for this study were provided by Samsung Medical Center BioBank.

\section{References}

1 Worzfeld $\mathrm{T}$ and Offermanns S: Semaphorins and plexins as therapeutic targets. Nat Rev Drug Discov 13: 603-621, 2014.

2 Kruger RP, Aurandt J and Guan KL: Semaphorins command cells to move. Nat Rev Mol Cell Biol 6: 789-800, 2005.

3 Shelly M, Cancedda L, Lim BK, Popescu AT, Cheng PL, Gao H and Poo MM: Semaphorin3A regulates neuronal polarization by suppressing axon formation and promoting dendrite growth. Neuron 71: 433-446, 2011.

4 Antipenko A, Himanen JP, van Leyen K, Nardi-Dei V, Lesniak J, Barton WA, Rajashankar KR, Lu M, Hoemme C, Puschel AW and Nikolov DB: Structure of the semaphorin-3A receptor binding module. Neuron 39: 589-598, 2003. 
5 Kumanogoh A and Kikutani H: Immunological functions of the neuropilins and plexins as receptors for semaphorins. Nat Rev Immunol 13: 802-814, 2013.

6 Pellet-Many C, Frankel P, Jia H and Zachary I: Neuropilins: structure, function and role in disease. Biochem J 411: 211-226, 2008.

7 Nasarre P, Gemmill RM and Drabkin HA: The emerging role of class-3 semaphorins and their neuropilin receptors in oncology. Onco Targets Ther 7: 1663-1687, 2014.

8 Law JW and Lee AY: The role of semaphorins and their receptors in gliomas. J Signal Transduct 2012: 902854, 2012.

9 Bagci T, Wu JK, Pfannl R, Ilag LL and Jay DG: Autocrine semaphorin 3A signaling promotes glioblastoma dispersal. Oncogene 28: 3537-3550, 2009.

$10 \mathrm{Hu}$ ZQ, Zhou SL, Zhou ZJ, Luo CB, Chen EB, Zhan H, Wang PC, Dai Z, Zhou J, Fan J and Huang XW: Overexpression of semaphorin $3 \mathrm{~A}$ promotes tumor progression and predicts poor prognosis in hepatocellular carcinoma after curative resection. Oncotarget 7: 51733-51746, 2016.

11 Muller MW, Giese NA, Swiercz JM, Ceyhan GO, Esposito I, Hinz U, Buchler P, Giese T, Buchler MW, Offermanns S and Friess H: Association of axon guidance factor semaphorin 3A with poor outcome in pancreatic cancer. Int J Cancer 121: 2421-2433, 2007.

12 Casazza A, Laoui D, Wenes M, Rizzolio S, Bassani N, Mambretti M, Deschoemaeker S, Van Ginderachter JA, Tamagnone L and Mazzone M: Impeding macrophage entry into hypoxic tumor areas by Sema3A/Nrp1 signaling blockade inhibits angiogenesis and restores antitumor immunity. Cancer Cell 24: 695-709, 2013.

13 Zhang J, Xu M, Zheng Q, Zhang Y, Ma W and Zhang Z: Blocking macrophage migration inhibitory factor activity alleviates mouse acute otitis media in vivo. Immunol Lett 162: 101-108, 2014.

14 Gil-Gil MJ, Mesia C, Rey M and Bruna J: Bevacizumab for the treatment of glioblastoma. Clin Med Insights Oncol 7: 123-135, 2013.

15 Goel HL and Mercurio AM: VEGF targets the tumour cell. Nat Rev Cancer 13: 871-882, 2013.

16 Acevedo LM, Barillas S, Weis SM, Gothert JR and Cheresh DA: Semaphorin 3A suppresses VEGF-mediated angiogenesis yet acts as a vascular permeability factor. Blood 111: 2674-2680, 2008.

17 Treps L, Edmond S, Harford-Wright E, Galan-Moya EM, Schmitt A, Azzi S, Citerne A, Bidere N, Ricard D and Gavard J: Extracellular vesicle-transported Semaphorin3A promotes vascular permeability in glioblastoma. Oncogene 35: 2615-2623, 2016.

18 Groppa E, Brkic S, Bovo E, Reginato S, Sacchi V, Di Maggio N, Muraro MG, Calabrese D, Heberer M, Gianni-Barrera R and Banfi A: VEGF dose regulates vascular stabilization through semaphorin $3 \mathrm{~A}$ and the neuropilin-1+ monocyte/TGF-beta1 paracrine axis. EMBO Mol Med 7: 1366-1384, 2015.

19 Lee J, Shin YJ, Lee K, Cho HJ, Sa JK, Lee SY, Kim SH, Lee J, Yoon Y and Nam DH: Anti-SEMA3A antibody: a novel therapeutic agent to suppress GBM tumor growth. Cancer Res Treat, 2017. https://doi.org/10.4143/crt.2017.315 [Epub ahead of print]

20 Becker PM, Tran TS, Delannoy MJ, He C, Shannon JM and McGrath-Morrow S: Semaphorin 3A contributes to distal pulmonary epithelial cell differentiation and lung morphogenesis. PLoS One 6: e27449, 2011.
21 Yazdani U and Terman JR: The semaphorins. Genome Biol 7: 211, 2006.

22 Tabrizi MA, Tseng CM and Roskos LK: Elimination mechanisms of therapeutic monoclonal antibodies. Drug Discov Today 11: 81-88, 2006.

23 Shah DK and Betts AM: Antibody biodistribution coefficients: inferring tissue concentrations of monoclonal antibodies based on the plasma concentrations in several preclinical species and human. MAbs 5: 297-305, 2013.

24 Uhlen M, Fagerberg L, Hallstrom BM, Lindskog C, Oksvold P, Mardinoglu A, Sivertsson A, Kampf C, Sjostedt E, Asplund A, Olsson I, Edlund K, Lundberg E, Navani S, Szigyarto CA, Odeberg J, Djureinovic D, Takanen JO, Hober S, Alm T, Edqvist PH, Berling H, Tegel H, Mulder J, Rockberg J, Nilsson P, Schwenk JM, Hamsten M, von Feilitzen K, Forsberg M, Persson L, Johansson F, Zwahlen M, von Heijne G, Nielsen J and Ponten F: Proteomics. Tissue-based map of the human proteome. Science 347: 1260419, 2015.

25 Polleux F, Morrow $\mathrm{T}$ and Ghosh A: Semaphorin 3A is a chemoattractant for cortical apical dendrites. Nature 404: 567573, 2000.

26 Polleux F, Giger RJ, Ginty DD, Kolodkin AL and Ghosh A: Patterning of cortical efferent projections by semaphorinneuropilin interactions. Science 282: 1904-1906, 1998.

27 Yang XD, Corvalan JR, Wang P, Roy CM and Davis CG: Fully human anti-interleukin- 8 monoclonal antibodies: potential therapeutics for the treatment of inflammatory disease states. $\mathrm{J}$ Leukoc Biol 66: 401-410, 1999.

28 Mahler DA, Huang S, Tabrizi M and Bell GM: Efficacy and safety of a monoclonal antibody recognizing interleukin- 8 in COPD: a pilot study. Chest 126: 926-934, 2004.

29 Hart TK, Cook RM, Zia-Amirhosseini P, Minthorn E, Sellers TS, Maleeff BE, Eustis S, Schwartz LW, Tsui P, Appelbaum ER, Martin EC, Bugelski PJ and Herzyk DJ: Preclinical efficacy and safety of mepolizumab (SB-240563), a humanized monoclonal antibody to IL-5, in cynomolgus monkeys. J Allergy Clin Immunol 108: 250-257, 2001.

30 Lin YS, Nguyen C, Mendoza JL, Escandon E, Fei D, Meng YG and Modi NB: Preclinical pharmacokinetics, interspecies scaling and tissue distribution of a humanized monoclonal antibody against vascular endothelial growth factor. J Pharmacol Exp Ther 288: 371-378, 1999

31 Zia-Amirhosseini P, Minthorn E, Benincosa LJ, Hart TK, Hottenstein CS, Tobia LA and Davis CB: Pharmacokinetics and pharmacodynamics of SB-240563, a humanized monoclonal antibody directed to human interleukin-5, in monkeys. J Pharmacol Exp Ther 291: 1060-1067, 1999. 